\title{
Absentia Voter in the Election of Regional Head in Situbondo Regency Year 2015
}

\author{
Rupiarsieh $^{1}$ \\ ${ }^{1}$ Social and Politic Faculty, Bojonegoro University, Indonesia \\ Correspondence: Rupiarsieh, Social and Politic Faculty, Bojonegoro University, Indonesia. E-mail: \\ arsieh_sakti@yahoo.com
}

Received: January 23, 2017

Accepted: March 30, 2017 Online Published: April 19, 2017

doi:10.5539/ass.v13n5p34

URL: https://doi.org/10.5539/ass.v13n5p34

\begin{abstract}
Since the downfall of the New Order regime, the regional head election is done directly. Before 2005, it was elected by the Local House of Representatives (Dewan Perwakilan Rakyat Daerah, DPRD). However, since the effectuation of Constitution No. 32 year 2004 said that the regional head was chosen directly by the people and called as Pilkada. It was held in 2010 and 2015. In the 2015 elections in Situbondo, the number of absentia voter is still a problem. It shows that the public has little or no political participation in using their right to vote freely. It is very influential on democracy and acceptance of the elected leaders. The 2015, it showed that the number of registered voters is 509,111 . Voters, who using their voting rights only 378,953 . The valid votes 372,555 , divided to first candidate in number of $18,997(5 \%)$, second candidate in number of $158,934(43 \%)$, and the third candidate in number of 194624 or $52 \%$. Total absentia voter is 130,058 (25\%). By using descriptive qualitative method, the simultaneous elections can be analyzed. The high absentee voter was more due to political factors, lack of political awareness because the majority of education level is still low, and there are patrialism in political culture is. All the leader must have the blessing from the moslem leader (Kiayi). The voters are not in accordance with the existing leader candidate, do not attend the election. The voters will attend the election by following the advice from the Kiayi. They chose their regency leader not in freely condition. If the elected regent unable to accommodate the interests of the opposing party (absentia voter) could become a powerful political opponent. A new factor affecting the absentee voter is political culture. The political culture and democracy education conducted by involving the Kiayi, and directed at women voters and beginner-voter, because the majority of voters are women and the beginner-voter are in the moslem boarding school (called: pasantren), that manage by the Kiayi.
\end{abstract}

Keywords: Absentia voter, the election of regional head, political awareness, political and democracy education

\section{Introduction}

\subsection{Introduce the Problem}

Since the fall of the New Order, the implementation of regional head election conducted directly. Before 2005, the regional head and deputy head of the region selected by the Local House of Representatives (DPRD). However, since the enactment of Law No. 32 of 2004 on Regional Government, the regional leaders were chosen directly by the people through Election, called Pilkada. In the district of Situbondo, first election held on 2010 and the second was held in 2015, which is also held in 19 other districts and cities in East Java.

Election is held directly in the hope that people can choose and determine directly the leader for the next 5 years, but in the 2015 elections of Situbondo number of absences (Absentia Voter) is still a problem. Based on studies showed that the absence of voters reached $25 \%$, and shows that the public has little or no political participation in to use their right to vote freely in the local elections. Though the election agenda, both at the national level (election) as well as at the level of local (election) is a form of the provision of facilities for citizens to participate in the use of their voting rights. When the voting right is ignored, then this will hurt democracy, that formulated as the government come from, by and for the people.

Absentia voter (the voter who was not present) could be interpreted as a group of people who had the vote, but did not vote in the elections. But in addition to the classification, absentia voters (voters who did not attend) also includes a number of voters that do not due to negligence of the administration by organizing institutions (KPU). 
Many factors that causes voters are more likely to abstain from voting. His apathetic is not just a form of mistrust of politicians right now, but rather the lack of political awareness of the people, plus their dominance of local political culture and the weakness of the electoral system itself.

The aims of this study, to find and describe all the affecting factors of the decrease in political participation, and the implementation of the election which is represented in absentia voters (voters who were not present), and to know why absentia voter will be the best choice. Simultaneously this study provides political education for the public at large, about the importance of political participation, especially participation in the elections through the use of their voting rights. On the basis of these reasons, researchers took the theme "Absentia voter in the election of regional head in Situbondo Regency year 2015".

\subsection{Absentia Voters}

Absentia voter (the voter who did not attend) is a deviant movement, and could weaken the legitimacy of the elected government power. But, absentia voters (voters who did not attend) is not only as a political gesture, but also considered as activities of a person who did not vote at the time of elections, either because of intentional problems or due to technical problems. Absentia voter (voters who did not attend) is defined as someone who did not come and did not choose at the time of the election, because it is motivated by a variety of factors.

In the theory of political participation, Colin Mc Andrews said that, the activities do not vote in elections classified into non-conventional political participation. It is also revealed by Milbrath M.L. Goel which identifies seven individual forms of political participation, which is inserted into the form of participation Apathetic Inactive, which is not active participatory, never vote in elections.

In many countries, with different terms and perspectives used, absentia voters (voters who did not attend) become a punishment for the political elite, because they are incapable of creating a state that aspired, as stipulated in the Constitution 1945. And this is, where the absentia voters (voters who did not attend) have a very important role, to use their political rights through participation not to use their right to vote.

In Indonesia, the absentia voters (voters who did not attend) takes place in each of the electoral operations and occur within a range of three orders, the old order. The presence of absentia voter (the voter who was not present) in every election, not solely political reasons, but also due to technical factors.

Absentia voter (the voter who did not attend) can be defined as the steps taken by the person / groups, who has the right to vote, but do not vote in the general elections, either intentional or unintentional reason. Unintentional reason could be due to many factors, such as technical factors are traveling, working, sick, political or technical factors such as the problems of citizens who already have the right to vote but not recorded by the administration as a voter. The phenomenon of absentia voters (voters who did not attend) is a political maneuver of the unsatisfactory people on the performance of public officials (by election) that far from political reality.

To the new era, if there are absentia voters (voters who did not attend), then it is considered as a moral movement to against the government. In reform era, that the vote is a right, so that absentia voters (voters who did not attend) is not only dominated by moral movement politically conscious not to use the right to vote, but also due to other factors.

According to Asfar, absentia concept is distinguished by the behavior of non-voting used to refer to the following phenomena (1) those who do not attend the polling station to protest, (2) a person who attended the polling place but did not use their voting rights properly, and (3) people who use their voting rights, but with the way piercing the white part of the election card. While non-voting behavior aimed not to motivated to vote. However, both terms refer to the same result of the act: the voting rights are not used correctly.

In complexity absentia voters, can be classified: (1) the groups of people who have voting rights constitutionally, but as a subject of the election was not listed definitively. (2) voters who inadvertently made a mistake in voting, (3) the people who really do not care about political affairs, or especially about elections, (4) the people who consciously and against electoral and political party systems.

In terms of political participation, absentia voters (voters who did not attend) is the right of every person to use or not to vote. Absentia voter (the voter who did not present) indicates those aspirations are not accommodated by the existing political system or it can also mean about political or apolitical people. The apathetic attitude of society is an accumulated disappointment with the existing political system.

In using the voting rights really depends on the person. According to Bruce Ackerman and James Fishkin (2003: 7), increasing absentia voters relates to the tendency of political culture in the society, which is what is referred to as 'civic privatism'. Within such a context, choose seen as a private issue and cannot be imposed. In this 
political culture, people tend to ignore to the political problems.

The trend of the phenomenon of absentee voters (voters who did not attend) in direct general election is basically not much different from the tendency of voting behavior that occurs in the elections at the national level, namely the critical and apathetic voters. A common characteristic of this model is distrust to the politicians. This tendency was also found in studies of voting behavior that shows that distrust of political parties and politicians in many countries are likely to increase (Diamond and Gunther 2001).

According to Norris, "declining voter participation rate was associated with a decline in the level of satisfaction of the performance of government". Included in this analysis is a decrease in the level of trust the voters against politicians (Franklin, 2004). This analysis is associated with the argument of voters that anyone who sits in government unbelievable because not able to fulfill its promises. In this case, all politicians have a similar tendency, which is trying to close the voter when the general elections and tend to stay away after the ruling.

In addition, the disillusionment with the party or candidate is also reflected in the pragmatism of the public / voters. Apparently in the public / voters are still plenty of narrow views who expect their money or rewards from candidates as consideration for their ballots. If no one party or candidate that reward, people also do not want to exercise their voting rights.

Charles Schaffer (2007) said, that Political money is a common phenomenon in competitive elections. Moreover, when the condition of the people is still in a poor state, as in Indonesia. The party program will not be effective to attract the sympathy of citizens. They are more interested in more concrete terms, the real help either in the form of goods or money. An election in a community whose inhabitants are mostly poor, it will be vulnerable to vote buying.

Herbert E. Alexander (2003) said, that in the presidential and the head of the region election directly by the people instead of money politics lead to opportunities for more wide open. Political money could occur through campaign contributions that exceeded the provision or donations are not reported, business role in supporting the campaign, using the mass media, and others.

According to Eep Saefulloh Fatah (2007), Absentia voter (the voter did not attend) can be identified as follows. (1) technical absentia, those who become non-voters for certain technical reasons (family died, fell asleep, and others) was unable to attend to the polls, or those who mistakenly cast to voice declared invalid. (2) Technical-political absentia, as they are not registered as a voter by mistake himself or another party (the statistical agency, organizer of the election). (3) Political absentia, those who felt no choice of available candidates or do not believe that the elections will bring changes and improvements. It is clear that people become non-voters for political consciousness. Society may feel bored and apathetic to the party that is considered only benefit for the political elite themselves.

Agus Riewanto (2008), divide the absentia voters into 3 types, namely (1) Ideological absentia were motivated ideological rejection of any kind of power products in particular and socio-political system in general. (2) Political absentia, is conducted due to political choices. This typology groups within society in general are trapped in a circle of alienation, that feeling alienated from politics or government. (3) Pragmatic absentia, that is the groups that appear based on rational calculation that no better impact to voters themselves.

The increasing cases of non-voters because of error that has spawned democratic imbalance in various fields. Activity leader election which too often makes people reluctant to participate when in reality their welfare is less assured.

\subsection{Democracy and Election in Situbondo Year 2015}

Democracy is a form of government that all citizens have equal rights in decision-making that can change lives. Democracy allow citizens to participate either directly or through representatives in the formulation, development, and manufacture of the law. Democracy includes the social, economic, and cultural practices that allow their political freedom freely and equally.

The word democracy comes from the two words "demos" meaning people and "kratos" meaning government, or in other words the basic meaning of democracy is government of the people, or the more we know as a government of the people, by the people and for the people.

Democracy defined by (1) Aristotle, said that the principle of democracy is freedom, because only through the freedom of every citizen can share power. (2) Henry B. Mayo, said that in a democratic political system, the general policy adopted by a government determined by a majority of elected representatives who monitored effectively by the people. (3) Poerbopranoto Koentjoro, saying that democracy is a system in which the people 
participate actively in the administration of the State. (4) According to Prof. Mr. Muhammad Yamin, democracy is the basis for the establishment of government and society in which govern or regulate power lawfully held by all members of society. (5) Samuel Huntington, also saying that democracy exists if the decision-makers collectively the most powerful in a system chosen through a general election that is fair, honest, and periodic and in the system of the candidates freely compete for votes and almost the entire adult population can be given voting rights.

Democracy is a form or mechanism of government system as an effort to realize the sovereignty of the people (citizens' power) over the country to be run by the government.

The pillars of democracy are the principle of trias politica, that divides the political power as executive, legislative and judicial; to be realized in three types of state institutions are independent of each other (independent) and are in a rank parallel to each other. The three types of state institutions are a government agency that has the authority to establish and implement the executive authority, the competent courts the authority of the judicial and legislative branches that have the authority to exercise power legislative. Under this system legeslatif decision made by the public or by a representative who shall cooperate and act according to the aspirations of the people it represents and who elected through the electoral process.

Based on the Constitution of the Republic of Indonesia Number 8 Year 2015 on the Amendment of the Law number 1 in 2015, on the determination of Government Regulation of Law No. 1 of 2014 on the election of governors, regents and mayors into law the Act Article 2 and Article 3 said that the election democratic management based on the principles of direct, public, free, confidential, honest, and fair elections held every five (5) years simultaneously throughout the territory of the Republic of Indonesia.

General Election 2015 in Situbondo conducted in accordance with the article 5, which includes two stages, namely preparation and implementation stages. Stages of preparation, which is carried out is an activity program planning and budgeting, preparation of regulatory conduct of elections, the preparation and adoption of technical guidelines for each stage of the conduct of elections, socialization / education / technical guidance, the establishment of an ad hock organizing committee, registration of election monitoring and voter registration. Stages organizing elections regent and vice-regent include determining the terms of the candidate, support individual candidates, registration candidate, campaigns, reports and audit campaign finance, procurement and distribution logistics election of regent and vice regent, polling and counting of votes at polling stations, recapitulation the results of the vote count, , determination elected pair post decision of the Court, proposing ratification of the appointment of the selected candidates.

\section{Method}

The research on the absentia voter (the voter who did not attend) in the elections of regional head of Situbondo in 2015, is qualitative research, which is in the process of data requires data that already exists in the form of text, images or opinions comments from people who have competent and relevant. Bogdan and Taylor $(1975 ; 5)$ said that the qualitative method is a procedure that produces descriptive data in the form of written words or spoken of people and observed behavior. The data collected in this study is document.

The implementation of the General Election 2015, began the stages of the preparations, continue with the election of the regent and deputy regent, determination of elected regent and deputy regent. and the results of interviews to commissioners Election Commission Situbondo, the Secretary and the relevant staff in Election Committee of Situbondo, public/voters, student/politicians/political parties and institutions in the Situbondo to be analyzed.

In the opinion of Lexy J. Moeloeng (2006: 6) qualitative research is the research resulted in the analysis procedure that does not use statistical analysis procedures or other means of quantification. Likewise, the analysis used in this study correspond to the type of data required, the method of analysis used as well the method descriptive and exploratory qualitative analysis.

\section{Results and Discussion}

\subsection{Situbondo Election 2015}

\subsubsection{Total Population by Age Group}

In 2015, Situbondo had a population of 779,330 people, consisting of 391,523 men and 407,816 women, for more details in Table 1.

From Table 1, it appears that the majority of Situbondo peoples only about $10 \%$ of the population does not have the right to vote, the others already have the right to vote. 
Table 1. Total population by age group in Situbondo year 2015

\begin{tabular}{cccc}
\hline Age & 2013 & 2014 & 2015 \\
\hline $0-4$ & 39,457 & 38,188 & $49,449,786$ \\
$5-9$ & 50,771 & 50,275 & 55,245 \\
$10-14$ & 57,693 & 56,995 & 56,065 \\
$15-19$ & 54,494 & 55,537 & 60,105 \\
$20-24$ & 64,432 & 63,105 & 66,32 \\
$25-29$ & 64,687 & 65,254 & 66,636 \\
$30-34$ & 66,769 & 67,937 & 64,839 \\
$35-39$ & 62,257 & 63,441 & 61,317 \\
$40-44$ & 62,191 & 62,03 & 59,661 \\
$45-49$ & 56,339 & 58,824 & 52,28 \\
$50-54$ & 52,443 & 53,639 & 49,224 \\
$55-59$ & 42,908 & 44,022 & 37,437 \\
$60-64$ & 35,846 & 37,862 & 30,264 \\
$65-69$ & 24,947 & 26,864 & 21,753 \\
$70-74$ & 20,726 & 21,143 & 32,958 \\
TOTAL & 25,145 & 26,915 & 799,339 \\
\hline
\end{tabular}

(Source: Dispenduk of Situbondo Regency 2015)

\subsubsection{The Population Seen from The Level of Education}

Level of education reflects how many people are already free of illiteracy, and the extent to which the population has a political consciousness. To determine the level of public education in detail can be seen in Table 2 .

Table 2. Total population by level of education in Situbondo year 2015

\begin{tabular}{cccc}
\hline Education Level & 2013 & 2014 & 2015 \\
\hline Elementary Ungratuduate & 39.712 & 45.080 & 48.191 \\
Elementary Graduate & 260.326 & 262.423 & 261.438 \\
Secondary Graduate & 89.416 & 90.701 & 91.160 \\
High School Graduate & 96.251 & 98.127 & 98.932 \\
Diploma Programme & 5.071 & 5.267 & 5.378 \\
S1 Graduate & 17.963 & 18.747 & 19.593 \\
S2 Graduate & 809 & 829 & 898 \\
S3 Graduate & 41 & 49 & 53 \\
\hline
\end{tabular}

(Source: Dispenduk of Situbondo Regency 2015)

\subsubsection{The Existence of Registered Voters}

The existence of the number of voters registered is vital data to the political process, due to the availability of accurate data of registered voters, then each candidate for Regent/Vice Regent will adopt a strategy to get the vote as much to be able to elected. Here the existence of registered voters in the 2015 .

Table 3. Number of registered participants

\begin{tabular}{|c|c|c|c|c|c|c|c|c|c|c|}
\hline & \multirow{2}{*}{$\begin{array}{c}\text { No } \\
\text { District }\end{array}$} & \multicolumn{3}{|c|}{ Registered Voters } & \multicolumn{3}{|c|}{$\begin{array}{l}\text { Registered Voters In } \\
\text { Additional Voters List }\end{array}$} & \multicolumn{3}{|c|}{ Total } \\
\hline & & $\mathrm{M}$ & $\mathrm{F}$ & Sum & $\mathrm{M}$ & $F$ & Sum & $\mathrm{M}$ & $\mathrm{F}$ & Sum \\
\hline 1 & Jatibanteng & 8,589 & 9,292 & 17,881 & 26 & 5 & 31 & 8,615 & 9,297 & 17,912 \\
\hline 2 & Besuki & 22,385 & 23,856 & 46,241 & 56 & 73 & 129 & 22,441 & 23,929 & 46,370 \\
\hline 3 & Suboh & 9,991 & 10,888 & 20,879 & 23 & 31 & 54 & 10,014 & 10,919 & 20,933 \\
\hline 4 & Mlandingan & 8,685 & 9,391 & 18,076 & 79 & 76 & 155 & 8,764 & 9,467 & 18,231 \\
\hline 5 & Kendit & 10,768 & 11,916 & 22,684 & 30 & 27 & 57 & 10,798 & 11,943 & 22,741 \\
\hline 6 & Panarukan & 19,661 & 21,444 & 41,105 & 196 & 265 & 461 & 19,857 & 21,709 & 41,566 \\
\hline 7 & Situbondo & 16,195 & 17,729 & 33,924 & 306 & 346 & 652 & 16,501 & 18,075 & 34,576 \\
\hline 8 & Panji & 23,963 & 26,470 & 50,433 & 183 & 209 & 392 & 24,146 & 26,679 & 50,825 \\
\hline
\end{tabular}




\begin{tabular}{ccccccccccc}
\hline 9 & Mangaran & 12,290 & 13,657 & 25,947 & 80 & 90 & 170 & 12,370 & 13,747 & 26,117 \\
10 & Kapongan & 13,509 & 14,701 & 28,210 & 187 & 186 & 373 & 13,696 & 14,887 & 28,583 \\
11 & Arjasa & 15,640 & 16,882 & 32,522 & 150 & 136 & 286 & 15,790 & 17,018 & 32,808 \\
12 & Jangkar & 14,037 & 15,382 & 29,419 & 180 & 187 & 367 & 14,217 & 15,569 & 29,786 \\
13 & Asembagus & 17,630 & 19,534 & 37,164 & 187 & 169 & 356 & 17,817 & 19,703 & 37,520 \\
14 & Banyuputih & 19,624 & 22,327 & 41,951 & 96 & 90 & 186 & 19,720 & 22,417 & 42,137 \\
15 & Sumbermalang & 10,624 & 11,212 & 21,836 & 83 & 65 & 148 & 10,707 & 11,277 & 21,984 \\
16 & Banyuglugur & 8,381 & 9,210 & 17,591 & 16 & 13 & 29 & 8,397 & 9,223 & 17,620 \\
17 & Bongatan & 9,189 & 10,170 & 19,359 & 17 & 26 & 43 & 9,206 & 10,196 & 19,402 \\
& Total & 241,161 & 264,061 & 505,222 & 1,895 & 1,994 & 3,889 & 24,3056 & 266,055 & 509,111 \\
\hline
\end{tabular}

(Source: Situbondo Ellection Commission Report (processed 2016))

From Table 3 showed that in 2015 elections, the number of registered voters is a majority of women, there is a difference of 22.999 votes or $26.605 \%$. The existence of female voters is greater than 2010 local election and the greatest female voices in the district then followed districts Panji, Besuki and District Banyuputih.

\subsubsection{Political Education}

To run the 2015 election properly, it needs political education by the Election Commission together with the organizing team at the level of districts. The targets of political education are directed to women, the first voters through schools, the disabilities persons, stakeholders, the general public, and through cultural performances, for more details as in the Table 4 .

Table 4. Schedule and target of political education

\begin{tabular}{|c|c|c|c|}
\hline No. & Target & Date & Notes \\
\hline 1 & Wowan & $05 / 09 / 2015$ & Fatayat and Nasufiah Aisyah Women \\
\hline 2 & Disabities Person & $07 / 09 / 2015$ & $\begin{array}{l}\text { Persons with disabilities are invited at the Commission for political } \\
\text { education and appointed as a resource for other friends }\end{array}$ \\
\hline \multirow{6}{*}{3} & First-time Voters & $\mathrm{n} / \mathrm{a}$ & $\mathrm{n} / \mathrm{a}$ \\
\hline & SMKAN 1 Banyuputih & $08 / 09 / 2015$ & $\mathrm{n} / \mathrm{a}$ \\
\hline & SMKAN Suboh & $14 / 09 / 2015$ & $\mathrm{n} / \mathrm{a}$ \\
\hline & SMKAN 1 Panji & $17 / 09 / 2015$ & $\mathrm{n} / \mathrm{a}$ \\
\hline & $\begin{array}{c}\text { Pesantren Banyuputih and } \\
\text { Glugur }\end{array}$ & $28 / 09 / 2015$ & $\mathrm{n} / \mathrm{a}$ \\
\hline & $\begin{array}{l}\text { SMA \& SMKN Ibrahim } \\
\text { Situbondo }\end{array}$ & $20 / 10 / 2015$ & $\mathrm{n} / \mathrm{a}$ \\
\hline \multirow{3}{*}{4} & Stakeholder: & $\mathrm{n} / \mathrm{a}$ & $\mathrm{n} / \mathrm{a}$ \\
\hline & Head of District & $23 / 09 / 2015$ & $\mathrm{n} / \mathrm{a}$ \\
\hline & Head of Village & $28 / 10 / 2015$ & $\mathrm{n} / \mathrm{a}$ \\
\hline 5 & Cadre of parties & $10 / 10 / 2015$ & $\mathrm{n} / \mathrm{a}$ \\
\hline 6 & General public & $\mathrm{n} / \mathrm{a}$ & $\begin{array}{l}\text { Ludruk show in } 3 \text { villages. } \\
\text { Radio/TV } \\
\text { Printing media }\end{array}$ \\
\hline
\end{tabular}

The elections are concerned with women voters and the first voters. It is based on the data registered voters whose majority are women and the first voters. The table IV explains that the goal of political education is not only the general public, but the district and the whole village heads, and the political parties are targeted in carrying out political education. Hopefully, the societies are aware and understanding that elections will succeed in term of democratic system, to determine the regional leaders in bringing prosperity and welfare of the Situbondo community in the next 5 years.

\subsubsection{Socialization of The Regional Head Election}

Socialization the election of regional head not only face to face approach, but also through print and electronic media, to reach of the wider society in spaceless and timeless. Socialization the election is the key to success of the election itself, because with intense socialization, the public will get the complete information about the election, the election procedures, and also get to know the candidate of leaders in Situbondo. 
The efforts have been made by the organizers of the election in 2015 with the aim of increasing the number of registered voters, the political participation of voters on the day of the election in order to improve local democracy in Situbondo regency.

In the Table 5 shows that the election in Situbondo is socialized by visual installation. as well as the invitation of the importance of the election to the general public, which consists district leaders, stakeholder, political parties and mass organizations. The 2016 election hopes to increase political participation. By increasing political awareness, it will minimize the absentia voters. In other side, peoples will understand the track record of the head leader candidates

Table 5. Socialisation of the regional head election using publication media

\begin{tabular}{|c|c|c|c|}
\hline No & Publication Media & Sum & Distribute / Installated \\
\hline 1 & installation of billboards of the election process & 23 & 17 Districts, in main road of 6 cities \\
\hline 2 & $\begin{array}{l}\text { installation of billboards of the candidate picture with the } \\
\text { candidates number }\end{array}$ & 23 & 17 District, in main road of 6 cities \\
\hline 3 & $\begin{array}{l}\text { installation of billboards of the candidate picture and the } \\
\text { debate schedule }\end{array}$ & 8 & main road east to west \\
\hline 4 & Banners call-election & 154 & District and villages \\
\hline 5 & installation of billboards and appeal to Village Leader & 10 & main road east to west \\
\hline 6 & Banner to invite people to the peace election & 88 & $\begin{array}{l}\text { Distributed to community organizations and } \\
\text { political party }\end{array}$ \\
\hline 7 & Mobile poster & 75 & sticker cadre political parties \\
\hline
\end{tabular}

\subsubsection{The Campaign}

The campaign is a delivery event of the vision and mission of the regent/ deputy regent candidate, to the entire community in order to gain support by getting many votes. Therefore, in this campaign, all candidates together with his campaign team will exert their strength, mind and heart to get the people sympathy to give their vote, for more than three months.

Table 6. The campaign of the regional head election

\begin{tabular}{cccc}
\hline No. & Type of Campaign & Quantity & Notes \\
\hline 1 & Dialog face to face & 33 & Every candidates/ commission schedule \\
2 & Peaceful parade & 1 & $\mathrm{n} / \mathrm{a}$ \\
3 & Leisurely strolling & 1 & $\mathrm{n} / \mathrm{a}$ \\
4 & Candidates Debate & 3 & All candidates \\
5 & General meeting & 1 & Every candidates / commission schedule \\
6 & Advertisement on TV & 14 & Every day/candidates \\
7 & Advertisement on radio & 14 & Every day/candidates \\
8 & Advertisement in mass media & 4 & Every candidate, near the election time \\
\hline
\end{tabular}

(Source: Report of election committee of regional head election)

From the Table 6 can be explained that each potential candidates have a very long time to introduce himself in the campaign with all forms, especially face-to-face dialogue is an effective event for a dialogue on target of each campaign team directly.

Likewise, the implementation of an election held to 3 times is very unusual for a candidate to demonstrate to the public how the style of communication, intelligence and understanding of the problems of society and how they provide a solution, as well as strategy to develop Situbondo the district for the economic prosperity of its people, without leaving the ethical and legal norms.

The community can assess the candidate deserves the mandate as Regional leader for next 5 years. Besides the campaign through advertising on TV, radio in 14 days, is the best strategy of the Commission to provide peoples to know and understand the figure of their potential leaders who will compete in the elections in 2015.

\subsubsection{The Election}

General Election of 2015 is the second direct election and implemented simultaneously throughout Indonesia. Situbondo including from 19 districts / cities in East Java Election simultaneously implementing in 2015. The results of the implementation are shown in the Table 7. 
Table 7. Percentage of voting rights number of users election of regent and vice regent in Situbondo year 2015

\begin{tabular}{|c|c|c|c|c|c|c|c|c|c|c|}
\hline \multirow[t]{2}{*}{ No } & \multirow[t]{2}{*}{ District } & \multicolumn{3}{|c|}{ Registered Voters } & \multicolumn{3}{|c|}{ The User of Voting Right } & \multicolumn{3}{|c|}{$\begin{array}{c}\text { Precentage } \\
\text { of the Voters Presence }\end{array}$} \\
\hline & & $\mathrm{M}$ & $\mathrm{F}$ & Sum & $\mathrm{M}$ & $\mathrm{F}$ & Sum & $\mathrm{M}$ & $\mathrm{F}$ & Sum \\
\hline 1 & Jatibanteng & 8,615 & 9,297 & 17,912 & 5,702 & 6,379 & 12,081 & $66 \%$ & $69 \%$ & $67 \%$ \\
\hline 2 & Besuki & 22,441 & 23,929 & 46,370 & 14,713 & 17,741 & 32,454 & $66 \%$ & $74 \%$ & $70 \%$ \\
\hline 3 & Suboh & 10,014 & 10,919 & 20,933 & 7,191 & 8,523 & 15,714 & $72 \%$ & $78 \%$ & $75 \%$ \\
\hline 4 & Mlandingan & 8,764 & 9,467 & 18,231 & 6,929 & 7,740 & 14,669 & $79 \%$ & $82 \%$ & $80 \%$ \\
\hline 5 & Kendit & 10,798 & 11,943 & 22,741 & 7,966 & 9,440 & 17,406 & $74 \%$ & $79 \%$ & $76 \%$ \\
\hline 6 & Panarukan & 19,857 & 21,709 & 41,566 & 13,928 & 15,965 & 29,893 & $70 \%$ & $74 \%$ & $72 \%$ \\
\hline 7 & Situbondo & 16,501 & 18,075 & 34,576 & 12,235 & 13,946 & 26,181 & $74 \%$ & $77 \%$ & $76 \%$ \\
\hline 8 & Panji & 24,146 & 26,679 & 50,825 & 19,053 & 22,064 & 41,117 & $79 \%$ & $83 \%$ & $81 \%$ \\
\hline 9 & Mangaran & 12,370 & 13,747 & 26,117 & 9,583 & 11,307 & 20,890 & $77 \%$ & $82 \%$ & $80 \%$ \\
\hline 10 & Kapongan & 13,696 & 14,887 & 28,583 & 11,278 & 12,694 & 23,972 & $82 \%$ & $85 \%$ & $84 \%$ \\
\hline 11 & Arjasa & 15,790 & 17,018 & 32,808 & 11,878 & 12,865 & 24,743 & $75 \%$ & $76 \%$ & $75 \%$ \\
\hline 12 & Jangkar & 14,217 & 15,569 & 29,786 & 10,977 & 12,564 & 23,541 & $77 \%$ & $81 \%$ & $79 \%$ \\
\hline 13 & Asembagus & 17,817 & 19,703 & 37,520 & 12,046 & 14,177 & 26,223 & $68 \%$ & $72 \%$ & $70 \%$ \\
\hline 14 & Banyuputih & 19,720 & 22,417 & 42,137 & 12,477 & 14,880 & 27,357 & $63 \%$ & $66 \%$ & $65 \%$ \\
\hline 15 & Sumbermalang & 10,707 & 11,277 & 21,984 & 7,068 & 8,124 & 15,192 & $66 \%$ & $72 \%$ & $69 \%$ \\
\hline 16 & Banyuglugur & 8,397 & 9,223 & 17,620 & 5,556 & 6,628 & 12,184 & $66 \%$ & $72 \%$ & $69 \%$ \\
\hline 17 & Bongatan & 9,206 & 10,196 & 19,402 & 7,136 & 8,200 & 15,336 & $78 \%$ & $80 \%$ & $79 \%$ \\
\hline & Total/average & 243,056 & 266,055 & 509,111 & 175,716 & 203,237 & 378,953 & $72 \%$ & $77 \%$ & $75 \%$ \\
\hline
\end{tabular}

(Source: Report of election committee of regional head election)

The Table 7 shows that registered voters who use their voting rights majority are women, which amounted to 203,237 or $15,66 \%$ larger than male voters, and total voters to vote a number of 378,953 or $75 \%$.

From the Table 8 can be explained that the absence of a majority in the 2015 election in the district Banyuputih by $35 \%$, followed by the District and Sub-district Jatibanteng, Banyuglugur 32\% to $31 \%$. Average absentia voters by $25 \%$. All three districts have a basis schools and the type of society is patrinial against kiayi or pesantren leaders. Then, the political culture adopted the culture of patrimonialism.

Table 8. Percentage of voters not Using suffrage election of Situbondo regent and vice regent 2015

\begin{tabular}{|c|c|c|c|c|c|c|c|c|c|c|}
\hline \multirow[t]{2}{*}{ No } & \multirow[t]{2}{*}{ District } & \multicolumn{3}{|c|}{ Registered voters } & \multicolumn{3}{|c|}{$\begin{array}{l}\text { Voters not using suffrage } \\
\text { election }\end{array}$} & \multicolumn{3}{|c|}{$\begin{array}{l}\text { Percentage of absentia } \\
\text { voters }\end{array}$} \\
\hline & & $\mathrm{M}$ & $\mathrm{F}$ & SUM & $\mathrm{M}$ & $\mathrm{F}$ & SUM & $\mathrm{M}$ & $\mathrm{F}$ & SUM \\
\hline 1 & Jatibanteng & 8,615 & 9,297 & 17,912 & 2,887 & 2,913 & 5,800 & 34 & 31 & 32 \\
\hline 2 & Besuki & 22,441 & 23,929 & 46,370 & 7,672 & 6,115 & 13,787 & 34 & 26 & 30 \\
\hline 3 & Suboh & 10,014 & 10,919 & 20,933 & 2,800 & 2,365 & 5,165 & 28 & 22 & 25 \\
\hline 4 & Mlandingan & 8,764 & 9,467 & 18,231 & 1,756 & 1,651 & 3,407 & 20 & 17 & 19 \\
\hline 5 & Kendit & 10,798 & 11,943 & 22,741 & 2,802 & 2,476 & 5,278 & 26 & 21 & 23 \\
\hline 6 & Panarukan & 19,857 & 21,709 & 41,566 & 5,733 & 5,479 & 11,212 & 29 & 25 & 27 \\
\hline 7 & Situbondo & 16,501 & 18,075 & 34,576 & 3,960 & 3,783 & 7,743 & 24 & 21 & 22 \\
\hline 8 & Panji & 24,146 & 26,679 & 50,825 & 4,910 & 4,406 & 9,316 & 20 & 17 & 18 \\
\hline 9 & Mangaran & 12,370 & 13,747 & 26,117 & 2,707 & 2,350 & 5,057 & 22 & 17 & 19 \\
\hline 10 & Kapongan & 13,696 & 14,887 & 28,583 & 2,231 & 2,007 & 4,238 & 16 & 13 & 15 \\
\hline 11 & Arjasa & 15,790 & 17,018 & 32,808 & 3,762 & 4,017 & 7,779 & 24 & 24 & 24 \\
\hline 12 & Jangkar & 14,217 & 15,569 & 29,786 & 3,060 & 2,818 & 5,878 & 22 & 18 & 20 \\
\hline 13 & Asembagus & 17,817 & 19,703 & 37,520 & 5,584 & 5,357 & 10,941 & 31 & 27 & 29 \\
\hline 14 & Banyuputih & 19,720 & 22,417 & 42,137 & 7,147 & 7,447 & 14,594 & 36 & 33 & 35 \\
\hline 15 & Sumbermalang & 10,707 & 11,277 & 21,984 & 3,556 & 3,088 & 6,644 & 33 & 27 & 30 \\
\hline 16 & Banyuglugur & 8,397 & 9,223 & 17,620 & 2,825 & 2,582 & 5,407 & 34 & 28 & 31 \\
\hline 17 & Bongatan & 9,206 & 10,196 & 19,402 & 2,053 & 1,970 & 4,023 & 22 & 19 & 21 \\
\hline & Total & 243,056 & 266,055 & $509 ., 112$ & 65,445 & 60,824 & 126,269 & 27 & 23 & 25 \\
\hline
\end{tabular}

(Source: Report of election committee of regional head election) 
The elections in 2015 in Situbondo, there are three (3) pairs of candidates, two pairs of candidates for new entrants and 1 pair is incumbent. The election results showed that the winner is the most established by a pair of number 3 at 194, 624 or $52 \%$ followed the pair number 2 amounted to 158,934 or $43 \%$ (see Table 9). Margin obtained from the pair number 3 and 2 are not so high, given the pair to 3 is partner incumbent. Absentia voters reached $25 \%$ indicate that they are more due to the absence of political and cultural factors in district Situbondo.

Table 9. Result of vote acquisition of regent and vice regent of situbondo in year

\begin{tabular}{cccccc}
\hline \multirow{2}{*}{ No } & District & \multicolumn{3}{c}{ Candidates Number } & Sum \\
\cline { 2 - 4 } & & 1 & 2 & 3 & 23,295 \\
2 & Jatibanteng & 474 & 9,987 & 12,834 & 31,778 \\
3 & Besuki & 2,119 & 15,501 & 14,167 & 15,445 \\
4 & Suboh & 1,609 & 6,819 & 8,017 & 14,491 \\
5 & Mlandingan & 1,425 & 7,141 & 6,925 & 17,124 \\
6 & Kendit & 1,175 & 6,125 & 9,824 & 29,317 \\
7 & Panarukan & 1,702 & 11,761 & 15,854 & 25,411 \\
8 & Situbondo & 1,279 & 10,888 & 13,244 & 40,266 \\
9 & Panji & 1,753 & 13,506 & 25.007 & 20,611 \\
10 & Mangaran & 6,821 & 6,728 & 10,062 & 23,656 \\
11 & Kapongan & 662 & 8,903 & 14,091 & 24,457 \\
12 & Arjasa & 526 & 7,969 & 15,962 & 23,295 \\
13 & Jangkar & 474 & 9,907 & 12,834 & 25,866 \\
14 & Asembagus & 799 & 10,904 & 14,163 & 27,020 \\
15 & Banyuputih & 781 & 16,151 & 10,088 & 14,937 \\
16 & Sumbermalang & 633 & 6,609 & 7,695 & 11,912 \\
17 & Banyuglugur & 1,044 & 5,742 & 5,126 & 15,126 \\
\hline & Bongatan & 431 & 8,184 & 6,511 & 372.555 \\
\hline
\end{tabular}

(Source: Report of election committee of regional head election)

\subsection{Factors that influence the absentia voters}

Factor that influence the absentia voters are:

1. Low Levels of Education, is correlated with political awereness of local communities. The avarege level of public education in Situbondo is primary, therefore political awareness is still low, and contribute to absentia voters in election in 2015. Although political education conducted by Election Committee as election organizers in conducting political education already well, underway with the main target women voters and the first voters.

2. The level of confidence in the government is declining, indicated the community desire to choose a new figure in the election the new regent/ deputy regent in 2015, and the emergence of a new figure who has the support of the Kiayi in Situbondo and the general public as well as government officials.

3. Political Culture, Situbondo is known as the city of the moslem students ( Kota Santri), and Solawat Nariyah Places, so the majority of its people are students in Pondok Pesantren. Situbondo district is divided into three regions, In the East consists of Banyu Putih, Asembagus, Jangkar and Arjasa. In this region there is a Salafi Al Safiyah Sukorjo. In the West consist of Bongatan, Mlandingan, Besuki, Semanding Jati Bening and Banyu Glugur, that influenced by Al Qodiri, and in the Central Region consists of Kapongan, Panji, Situnondo, Panarukan and Kendit is influenced by Wali Songo and Sumber Bunga. The relation between the Kiayi and his students (Santri) are very strong, so what form the decision and the will of Kiayi will be followed by his Santri. This patron client bonds also occurs in elections in 2015. If the candidate is an alumnus of certain Pondok Pasantren, then the candidate will be supported by Kiayi and his Santri. If the candidate do not come from the same idealism, even though the candidate is in the same neighborhood, they will reject.

4. Unable to attend (out of town), will be the factors that influence the voter is not present in the election. They think, the choice to go outside the city is better than attended the election. This is an apathetic behavior in political awereness. 


\section{Conclusion and Recommendation}

The Factors influencing absentia voters in Elections of Regional Head 2015 are: (1) Low level of education which correlates to the low political awareness; (2) The trust level to the government is decreased that indicated the communities desire to choose a new figure in the election of the regent / deputy regent new in 2015. (3) The emersion of a new figure who has the support of the Kiayi in Situbondo and the general public. As well as government officials who prefer to choose another candidate than incumbent candidate. (4) There is political culture of patron client, from the Kiayi to the public on its common, this is a new finding, that the political culture has contributed significantly to the absence of voters (absentia voters) in the 2015 election in Situbondo, and (5) The apathetic behavior in political awareness, by choosing to go out of town than at present in the elections.

In order for this study can contribute to society's political participation in the election, the researchers suggest the following:

(1) Political Education implemented with the involvement of Kyai, and directed at women voters and the first voters, because the majority of voters are women and the first voters are in Pondok Pesantren.

(2) In anticipation of a high rate of absentia voters (voters who did not attend), the Election Commission and the candidate leader must improve the socialization by giving the political education about the importance of democracy to the nation and the state; so that voters are aware and willing to be ellection participants.

\section{References}

Ackerman, B., \& Fishkin, J. (2004). Deliberation Day. New Heaven \& London: Yale University Press.

Ali, N. (1999). Peradaban Komunikasi Politik (Potret Manusia Indonesia). Phil. Rosda, Bandung.

Arikunto, S. (1993). Prosedur Penelitian (Suatu Pendekatan Praktek). Rineke Cipta, Jakarta.

Berinsky, A. J., \& Gabrierl, L. S. (2010). Educations and Political Participations; Exploring the Causal Link. Springer Science + bisniss Media, LLC.

Bogdan, R. A. (1992). Pengantar Metode Penelitian Kualitatif. Usaha Nasional, Surabaya.

Eep, S. F., \& Fathah, D. H. M. N. Fenomena golput dalam krisi kepercayaan. Retrieved from http/lampungpos.com

Faturohman, Deden dan Sobri, Wawan. (2002). Pengantar Ilmu Politik. UMM Press, Malang.

Firmanzah. (2006). Marketing Politik Antara Pemahaman dan Realitas. Yayasan Obor Indonesia, Jakarta.

Harrison, L. (2007). Metodologi Penelitian Politik. Kencana, Jakarta.

Hebert, A. E. (2003). Financing Politics / Politik Uang Dalam pemilihan Presiden Secara Langsung pengalaman amerika Serikat. Univercity of Southern California.

Huntington, S. P. (1991). Gelombang Demokratisasi Ketiga.

Itoh, M. (2008, November). Voting In Absentia.

Jurnal Dialog Kebijakan Publik. (2008). Fenomena Golput Dari Tahun Ke Tahun. Departemen Komunikasi dan Informatika.

Keputusan KPU Kabupaten Situbondo, Nomor 02/Kpts/KPU-Kab-014.329894/2015, Tentang Tahapan, Program dan Jadwal Penyelenggaraan pemilihan Bupati dan wakil Bupati Situbondo 2015.

KPU Situbondo. Buku Laporan Pilkada 2015; Pelaksanaan Pemilihan Bupati dan Wakil Bupati Situbondo 2015, Januari 2016.

Mas'oed, M., \& McAndrews, C. (1995). Perbandingan Sistem Politik. Yogyakarta: Gadjah Mada University Press.

Mask, F. N. (2004). Voter Turn out and The Dynamics of Electoral Compettitions in Established Democracies Sice 1945. Canbridge University Press.

Mayo, H. B. (1960). An Introduction to Democracy Theory. Oxford University Press.

Michigan Senate Gov: No - Exuse Absentee Voting, Michigan Senate/Gov/sfa/Publication/Absentee. American Journal Political Science.

Milbrath, L. W. (1981). Political Participation, The Hand Book of Political Behaviour. New York: Plenum Press. 
Moleong Lexi, J. (2006). Metodologi Penelitian Kualitatif. Remaja Rosdakarya, Bandung.

Peraturan KPU Nomor 4 Tahun 2014.

Peraturan KPU tentang Tahapan, Program, dan Jadwal Penyelenggaraan Pemilu Presiden dan Wakil Presiden Tahun 2014.

Pippa, N. (2004). Electoral Enginering, Voting Rules and political Behaviour. Harold University Cambridge.

Poerbopranoto, K. (1975). Sedikit tentang Sistem Pemerintahan Demokrasi. Bandung, Eresco.

Purwoko, B. (2006). Demokrasi Mencari Bentuk. Program S2 Politik Lokal dan Otonomi Daerah Universitas Gadjah Mada, Yogyakarta.

Reinhard, G., \& Larry, D. (2001). Political Parties and Democracy. The John Hopkins University Press.

Schaffer, F. C. (1998). Democracy in Translation: Understandingpolitics in an unfamiliar culture. Cornel University Press, Ithaca and London.

Thomson Gale. (2008). Encyclopedia Internationala of the Politicial Sciences. Political Participating.

Undang Undang Republik Indonesia Nomor 8 Tahun 2015, tentang Perubahan Atas Undang Udang nomor 1 tahun 2015, tentang penetapan Peraturan pemerintah Pengganti Undang Undang Nomor 1 tahun 2014 tentang Pemilihan Gubernur, Bupati dan Walikota menjadi undang Undang.

Wahid, KH Abdurrahman, HD, Halim. (2009). Mengapa Kami Memilih Golput. SAGON.

\section{Copyrights}

Copyright for this article is retained by the author(s), with first publication rights granted to the journal.

This is an open-access article distributed under the terms and conditions of the Creative Commons Attribution license (http://creativecommons.org/licenses/by/4.0/). 